Studia Judaica 21 (2018), nr 1 (41), s. 55-76

doi:10.4467/24500100STJ.18.004.9174

Dina Katan Ben-Zion

\title{
A Symphony of Unique Voices: The Literary Testimony of Jewish Women Writers in Post-World War II Yugoslavia
}

\begin{abstract}
The first part of this article endeavors to give an idea about the scope and impact of dealing with Jews and Jewish issues in the literature of the former Yugoslavia, so as to provide a frame of reference for presenting in the second part the literary testimonies of several less-known Yugoslav Jewish women writers. In the second part, the writings of thirteen Jewish women writers will be presented. Their writings represent personal testimonies of literary heroines, while revealing some of the writers' literary strategies to preserve past-time memories, which in many ways characterize the specific feminine experience of a Yugoslav Jewish woman in the postwar period. ${ }^{1}$
\end{abstract}

Keywords: Jewish women writers, female outlook in literature, cultural legacy, dual belonging, strategies of preserving the memory, individual testimony and collective memory.

\section{Foreword}

As a translator and literary scholar who as a child came to Israel from the former Yugoslavia, I have for many years engaged in translating into Hebrew the best-known ex-Yugoslav writers, as well as researching Jewish themes that permeate a considerable part of the literature written in this

${ }^{1}$ In the Appendix, I have listed the names of 37 Jewish women writers in the former Yugoslavia. An extensive study dealing with the writings of four of them may be found in my Ph.D. thesis, followed by a book named Nashim kotvot 'olam: sofrot yehudiyot beYugoslavia leshe-avar (Jerusalem, 2013) as well as in the article "The Feminine Voyage in the Post-Holocaust Jewish Literature of Former Yugoslavia," published in Interkulturalnost 7 (2014), 186-191. 
country by both Jewish and non-Jewish writers in the second half of the twentieth century.

I have been attracted to this theme partly out of personal curiosity: what is it that writers in Yugoslavia could tell me about the past, both recent and distant, about the Jews of Yugoslavia? How do memories of the past turn their work into an integral part of our contemporary reality? How do they conceive and express the experiences of their early years, given that as adults they still lived in their childhood towns, to write as adults free from the repression and de-legitimation of past times' traumas? Writing in their mother's tongue, they aimed to reach the public who were (as were the writers themselves) victims of the horrors of World War II in the same country, and who therefore could relate to the Holocaust merely as part of the huge calamity that befell their country and their nation. How did those writers relate to their Jewishness not as Israelis, as Israel was not their ultimate goal? Finally, my motivation in researching this topic has apparently also been my attempt to deepen and enrich my own Israeli identity, since as a child growing up in Israel I carried distant memories of the Serbo-Croatian language and of the former Yugoslavia as a country. Those memories were imprinted upon many experiences throughout my life.

This article deals with the work of thirteen Jewish women writers, mentioning some of their published work, selected mainly with regards to their contribution to cultural representations of memory, and focusing in this case on the feminine experience and outlook. Its first part endeavors to give an idea of the scope and impact of Jewish themes in the literature of the former Yugoslavia, ${ }^{2}$ and thus provides a frame of reference for dealing with some of the literary testimonies of Yugoslav Jewish women writers. The second part presents some of the writings of several less-known Yugoslav Jewish women writers as they represent the personal testimonies of their female protagonists. Their writings reveal unique literary strategies intended to preserve memories of different times and circumstances. In many ways those memories illustrate the specific feminine experience of Yugoslav Jewish women in the post-World War II period.

${ }^{2}$ Further details see in the English translation of the Foreword and Afterword of my extensive study Nohehut ve-healmut: Yehudim ve-yahadut be-Yugoslavia leshe-avar birei ha-sifrut (Jerusalem, 2002). The English translation of the above parts was published in Lamed-E no. 3 (Summer 2009), selected and edited by Ivan Ninić. 


\section{Jews and Judaism in Former Yugoslavia in the Mirror of Literature}

Given that out of the total population of twenty million in the former Yugoslavia only about seven thousand Jews remained in the country, the sheer quantity of books about Jews and Judaism there seems to be a unique phenomenon which has thus been described in three (published) academic studies. ${ }^{3}$ Since some of the best-known and most appreciated Yugoslav writers in the second half of the twentieth century wrote about Jewish destiny and the problem of Jewish identity after the Holocaust, ${ }^{4}$ those studies deal with an apparently extraordinary phenomenon, though each takes a different point of view.

After the Holocaust, Yugoslav Jewish writers found themselves in an orphaned community; about 80 per cent of its members had perished. ${ }^{5}$ The new environment, fostered by the socialist ideology of the Yugoslav federation, was primarily secular while religious traditions were delegated to cultural heritage. The core of Jewish identity became characterized as "dual belonging." In the heterogenic multinational, multi-ethnic, and multi-religious postwar Yugoslavia, with a small Jewish community composed of both Sephardic and Ashkenazi Holocaust survivors, in a secular environment, the only common "Jewish" denominators consisted of (a) belonging to the Jewish community; (b) exhibiting a vague interest in Jewish heritage and Jewish age-old thought and wisdom; and (c) having a strong sense of a unique common destiny.

The quest for Jewish identity in the post-Holocaust era, along with questions about the relation of Jews to Judaism, as well as other topics about Jews and Judaism, became a central issue for an outstanding number of Yugoslav Jewish and non-Jewish writers. The abundance of their literary works represents a challenging phenomenon due to their quantity, diversity, and high literary standards.

Since issues related to Jewish identity in the former Yugoslavia in the post-Holocaust era inevitably involve trauma, writers of Jewish origin have dealt intensely with various aspects of the major distresses suffered by their generation. In fact, the Holocaust of Yugoslav Jews became the

\footnotetext{
${ }_{3}^{3}$ Predrag Palavestra, Jevrejski pisci u srpskoj književnosti (Beograd, 1998); Katan BenZion, Nohehut ve-healmut; ead., Nashim kotvot 'olam.

${ }^{4}$ Danilo Kiš, Aleksandar Tišma, David Albahari, Filip David, Erih Koš, Oskar Davičo and many others.

5 The pre-war Jewish population amounted to 78,000 Jews.
} 
criterion for measuring both the memory of Jewish pre-war history and an evolving sense of a new identity that began to emerge in its aftermath. With great talent, those writers portrayed (a) the traumatic consequences of persecutions and exterminations on Holocaust survivors; (b) the implications of the extermination of Jews and the horrors of racial and/or political persecution in a worldwide context; and (c) the survivors' unique sense of loss and quest for identity in a changed environment, against the background of the turbulent socio-political world, where they were tossed between extremes in a relatively short period of about 60 years.

As a literary phenomenon, the abundance of Jewish themes in postWorld War II Yugoslav literature is of interest spiritually, intellectually, and culturally. During that time there was a disproportionate relationship between the numerical impact of the tiny Jewish minority (about 7,000 listed members, after half of the survivors immigrated to Israel at the end of the 1940s), and the Yugoslav overall population (of about twenty million). Indeed, the mere fact that so many significant literary works in Serbo-Croatian deal with Jewish issues may, paradoxically, be attributed to Netzah Israel (Israel Eternity), as a perpetuation of Jewish thought even under extremely adverse conditions. All this took place of course before the dismemberment of the Yugoslav federation in the early 1990s.

Danilo Kiš, Aleksandar Tišma, David Albahari, and Filip David are notable writers even outside their own country. Each is unique in both subject matter and style, each an individual face mirroring the versatility of Jewish post-Holocaust existence as well as the diversity of forms that characterize secular Jewish thinking and discourse. They are perhaps best known for their involvement with Jews and their history, although other popular Yugoslav writers have taken up such issues as Jewish origin, identity, and destiny in their novels and short stories-among them Erih Koš, Oskar Davičo, Žak Konfino, Isak Samokovlija, Stanislav Vinaver, and others, ${ }^{6}$ also some well-known non-Jewish writers such as Ivo Andrić and Milorad Pavić.

Jewish issues, as explored by those authors in their quests for identity, stood out against the general trend of Yugoslavism, which aimed to erase

${ }^{6}$ In addition to the above-mentioned authors, the following Jewish writers dealt with Jewish issues: Hinko Gottlieb, Oto Bihalji-Merin, Moni de Buli, Danilo Nahmijas, Đorđe Lebović, Nebojša Glišić, Ervin Šinko, Miroslav Feldman, Berta Bojetu-Boeta, Sonja Nahman Premeru. Those are a few names out of more than a hundred Jewish writers who were active throughout the twentieth century in the ex-Yugoslav countries. For further details see: Palavestra, Jevrejski pisci; Katan Ben-Zion, Nohehut ve-healmut; ead., Nashim kotvot 'olam. 
all particularities and create a unified "all Yugoslav" culture, as described in Andrew Baruch Wachtel's illuminating study of the evolution of the idea of Yugoslav national unity and the ways of its implementation, presented as a critical factor in the long-term viability of the Yugoslav federation. ${ }^{7}$ However, those writers who experienced World War II as children or youngsters endeavored in their adult lives to describe past horrors, remembering how Jews were suddenly excommunicated and outlawed. ${ }^{8}$ Now Jews belonged to the new order that declared equality and brotherhood for all Yugoslav nations. It seems that in a rapidly changing world each experimented with original literary genres by creating a unique personal style as a tool to convey the Jewish post-Holocaust trauma embedded in their life experiences as citizens of the "brave new world."

The abundance of Jewish themes and issues in the post-Holocaust literature of the former Yugoslavia raises questions about the motivating force behind this phenomenon. Does canonical literature dealing with those questions indicate that a Jewish theme served perhaps as a kind of test case for the concept of Yugoslavism, or was it eventually only an ephemeral "trend"? Also, to what extent does the need to refer in literature to elements of Jewish life as well as to traditional Jewish symbols reflect profound existential anxiety, perpetuated by the state policy which aimed to erase all particularities and create a unified "all Yugoslav" culture? In the new post-Holocaust ambience, Jewish literature in this country manifested the need to redefine a connection to crucial heritage that was no longer taken for granted.

Finally, with the appearance of Jewish themes in Yugoslav postwar literature, the question has concerned how to present the specific experience of Jews-historical as well as recent-within the context of a new post-Holocaust reality. The literature created by each of the best-known writers became a vessel containing the author's individual experience and specific outlook in terms of both subject matter and literary form.

Andrew Baruch Wachtel, Making a Nation, Breaking a Nation: Literature and Cultural Politics in Yugoslavia (Stanford, 1998). According to Wachtel it was implemented in four major areas: linguistic policies aiming at creating a shared national language; the promulgation of a Yugoslav literary and artistic canon; an educational policy with regard to teaching literature and history in schools; and production of new literary and artistic works incorporating a Yugoslav view.

${ }^{8}$ As for instance: David Albahari, Gec i Majer (Beograd, 1998) and Mamac (Beograd, 2005); Danilo Kiš, Mansarda (Beograd, 1962), Psalam 44 (Beograd, 1962), Bašta, pepeo (Beograd, 1965), and Peščanik (Beograd, 1972); Aleksandar Tišma, Upotreba čoveka (Beograd, 1977), and Knjiga o Blamu (Beograd, 1980). 
Since the old world had collapsed along with traditional literary norms and forms, each of these writers created a new literary style to voice the specific Jewish loss and quest for identity in terms of the new reality, in which Jews found themselves orphaned of their families and communities, in search of a spiritual home that could contain the memories, questions, fears, and hopes of a small and diminishing Jewish minority. ${ }^{9}$

Given this background, many of the writers cited above are considered innovators who sought and produced new literary forms. Almost every one of their books was groundbreaking in terms of new genres and novel literary forms.

The same issues are present in the works of Yugoslav Jewish women writers, who described the specific feminine life experience. It was only later in my life that as a literary translator and scholar I came to realize the impact of the "feminine voyage" in this specific literary corpus. However, with perhaps the exception of Judita Šalgo, who experimented with the literary form, and to some extent Ana Šomlo, most of the literature created by Jewish women writers is generally realistic, delivered as a life story of the heroine, written out of an evident urge to "let the world know," emerging from a basic drive to provide truthful testimony based on the insights of a woman reflecting on the impact of past events on herself and her generation.

The female perspective embedded in their work is unique as it conveys feminine status, position, and outlook in a changed world, while patriarchal conceptions and practices were still deeply rooted in society, along with a new recognition of feminine capacity and potential. In the women's writings, females are portrayed as basically independent, self-reliant, and confident individuals rather than as weak, frustrated, or merely victimized. Furthermore, this body of literature describes the feminine journey, written from the perspective of women's authentic experience, life philosophy, and capacity for sustaining relationships.

${ }^{9}$ See also: Dina Katan Ben-Zion, "Tangled Fragments of Identity in a Changing World: Judaism as an Open Question in the Literature of Former Yugoslavia," in Hillel Weiss, Roman Katsman, Ber Kotlerman (eds.), Around the Point: Studies in Jewish Literature and Culture in Multiple Languages (Newcastle upon Tyne, 2014), 453-478. 


\section{Specific Contributions of Jewish Women Writers: Personal Testimonies as Building Blocks of a Collective Memory}

The purpose of this section is to present aspects of Jewish consciousness in the writings of thirteen Jewish women writers in the former Yugoslavia, by briefly first presenting four-Frida Filipović, Gordana Kuić, Judita Šalgo, and Ana Šomlo-whose writings I have extensively discussed in my research. ${ }^{10}$ I will then discuss other writers (all of whom lived and wrote in Yugoslavia in the second half of the twentieth century) whose Jewish topics and unique insights into the Jewish female lot are worth noting.

\section{Frida Filipović (1913-2003)}

Frida Filipović was the first writer in her country to deal with the sexual exploitation of Jewish women in the Nazi camps, as well as with the crimes of human experimentation carried out by German doctors on prisoners of Nazi concentration camps.

In 1967, a film based on Filipović's screen play, Gorke trave [Bitter Herbs], came out. In this film Leah Weiss, a Polish Jew, was shown forced into prostitution in Auschwitz. She later became a victim of medical experimentation. Twenty years later, German war crime prosecutors hoped she would be their star witness. The heroine is subjected to the unbearable stress of shame in having to relive those experiences.

In 2000, Filipović published Bitter Herbs, this time as a novel. Part of her strategy was to combine a short novella, published in 1973 in the collection Razilaženja [Going Apart], with the plot of the earlier film. The first part_-based on the novella_-deals with the significance of being a Jewish woman who acknowledges the authenticity of her Jewish origin as her true identity, despite the fact that as a young girl she had felt alienated. After the war, the heroine of Bitter Herbs suffers from both the traumatic results of sexual exploitation and from persecution by Neo-Nazis, who intended to prevent her from appearing as a witness at their trial. Though portrayed as having a strong personality and being self-reliant, her heroine is tragically defeated by the same political evil that brought about her calamity, as well as that of other women.

${ }^{10}$ For those four women writers, see also my article based on a lecture delivered at the Yad Vashem Conference held in 2013: Katan Ben-Zion, "The Feminine Voyage." 


\section{Gordana Kuić (b. 1942)}

Gordana Kuić published eight novels and collections of short stories, constituting a unique literary cosmos which portrays Sephardic Jews, beginning with the expulsion from Spain and detailing their personal destinies as they wander the Balkans. Regardless of their personal stories, her protagonists always feel deeply involved in the life of their neighbors and fellow citizens; they lack any sense of alienation or estrangement.

Kuić's literary opus is based on recognizing the paradigm of true love and devotion to one's family as an essential component of the Sephardic sense of identity. Her worldview reflects the idea of "secular grace," of imbuing a secular humanist meaning to the religious notion of grace. ${ }^{11}$ Specifically, she portrays family relations in terms of the sense of a profound belonging to both one's unique mother tongue and to a multi-faced social environment endowed by blessed diversity.

\section{Judita Šalgo (1941-1996)}

In Judita Šalgo's writings, the sense of Jewish identity displays an intricate combination of mythic, social, philosophical, and personal insights. These elements are interwoven with the consciousness of injustices toward the weak and outcasts, including women dominated by patriarchal conceptions and practices. Her last dystopian novel, Put u Birobidžan [The Way to Birobidjan] (Beograd, 1997), published posthumously, portrays a place reigned by justice, free from abuse, exploitation, and oppression, as a shelter providing defense and healing for all outcasts and victimized individuals, among them women as an oppressed group.

\section{Ana Šomlo (b. 1934)}

In all her novels, Ana Šomlo's protagonists reveal a profound sense of belonging to an age-old Jewish consciousness rooted in Jewish scripts and wisdom, as well as an awareness of living where her ancestors had dwelled for ages. Her heroine, a journalist, cleverly uses her bold spirit

11 This idea is presented and discussed in the studies of Dana Freibach-Heifetz, Hahesed ha-hiloni (Tel Aviv, 2009), and of Tsippy Levin Byron, Ro'a shel nemerim: Shkiei zehut yehudit bi-ytsirata shel Natalia Ginzsburg (Tel Aviv, 2015). 
and wit to point out the evils which women were subjected to by men in key positions. More specifically, along with her heroine's memories of the Jewish pre-war past and the loss suffered in consequence to the Holocaust, Šmlo exposes the political regime's stupidity and patriarchal practices, namely, of victimizing women while taking advantage of their services.

Šmlo published two of her novels twice, so as to make her voice fully heard. The first instance was the publication of her novel Lea Straser (1980) - for which publication norms required partial deletions-in full, including her sharp critique, titled Žuti prkos [The Yellow Defiance] ${ }^{12}$ which appeared in 2006 and in a sophisticated manner combined memories of the heroine's family who perished in the Holocaust, interwoven into the life circumstances of her protagonist and her emotional state as a young journalist, a single survivor of her family, living in postwar Yugoslavia. Similarly, in 2005 Šomlo produced her epistolary novel of Milena Jesenská's imaginary letters to Kafka, which had appeared in 1988 without arousing the interest it deserved as a brilliant literary accomplishment; ${ }^{13}$ here she changed its title to Bila sam tvoje more: Prepiska Franca Kafke $i$ Milene Jesenske [I Have Been Your Sea: The Correspondence of Milena Jesenská with Franz Kafka], and this time included Kafka's original letters. ${ }^{14}$

\section{Jasminka Domaš (b. 1948)}

Jasminka Domaš is a poet, novelist, lecturer, and journalist, well known in Croatia, whose works have been translated into several languages. She graduated from the Faculty of Political Sciences at the University of Zagreb, and has become an expert in biblical and modern Judaism; currently she is a lecturer in Jewish studies. Among the fifteen books she has published in Zagreb is the collection of short stories Tjedne minijature slobode [Weekly Miniatures of Freedom; 1997]; the collections of essays Šabat Šalom ${ }^{15}$ (1999); I Bog moli [God Also Prays; 2013]; Dan po dan [From Day to Day; 2014]; reflections on biblical stories Biblijske priče [Biblical Stories; 2000]; studies of Jewish mysticism and trends of thought

12 Ana Šomlo, Žuti prkos (Beograd, 2006).

13 Ana Šomlo, Milenina pisma Kafki (Novi Sad, 1988).

14 Ana Šomlo, Bila sam tvoje more: Prepiska Franca Kafke i Milene Jesenske (Beograd, 2005).

${ }^{15}$ The word "Shabbat" is the Hebrew word for Saturday; "shalom" in Hebrew is the word for peace, used as a common everyday greeting. $\breve{S}$ abat $\breve{S}$ alom as a greeting, used on Friday evening and Saturday, means wishing a peaceful Shabbat. 
Židovska meditacija - istraživanje mističnih staza judaizma [Jewish Meditation: Studies of Mystic Trends in Judaism; 2003]; 72 imena Boga [72 Names of God; 2008]; the recollections Glasovi, sjećanja, život - prilog istraživanju povijesti židovskih obitelji [Voices, Memories, Life: A Contribution to the Research of Jewish History; 2015]; a collection of poetry Žena Sufi [A Sufi Woman; 2014]; as well as the three novels Rebeka u nutrini duše [Rebecca in the Interior of Her Soul; 2001]; Nebo na zemlji [Heaven on Earth; 2010]; Knjiga o ljubavi ili kako sam srela Anu Frank [The Book on Love or How I Met Anne Frank; 2004]—a novel dealing with a contemporary woman's position.

Domašs first book, Obitelj - Mishpaha [The Mishpaha Family; 1996], is a study of the Jewish community in Croatia and its deep roots in the spiritual life there and in European culture. The extensive body of her literary work focuses on representing the rich heritage of Mahshevet Israel, Jewish age-old wisdom, studied, comprehended, and presented to the reader via literature. Her work is therefore a valuable cultural asset, in many ways as relevant today as when it was written. In her novels Domaš explores her heroine's innermost feelings and thoughts, who was entrapped by the heavy impact of the recent past's calamities and the urge to transcend victimization in order to be able to live life fully. In Heaven on Earth she presents three generations of women, each striving to make the most of her lot in life. Domaš's novels deal with women's roles in modern society, mainly from a Jewish perspective. They focus in many ways on trends of thought and practices based on Judaism as a set of cultural assets and moral values preserved by tradition, that could be re-interpreted and applied to a different time and environment. In her recent novel Izabrana: Život Edith Štein [The Chosen One: The Life of Edith Stein; 2017], Domaš writes about the life and the spiritual realm of Edith Stein (1891-1942), known also as St. Teresa Benedicta of the Cross. Stein was a German Jewish philosopher who converted to Roman Catholicism and became a Carmelite nun. She died at the gas chamber in Auschwitz. Upon her death she was canonized as a martyr and saint of the Catholic Church. Reflecting on the unique destiny of Edith Stein, Domaš deals with aspects of identity in modern times. 


\section{Zora Dirnbah (b. 1929)}

Born in Osijek, Zora Dirnbah is a playwright and novelist who published her first works in the 1950s. A film based on her script Deveti krug [The Ninth Circle; 1960] gained her wide recognition in her country. In addition to plays and films, she published several novels and short-story collections, all concerned with Jewish destiny before, during, and after World War II. In 1996 she published a collection of biblical stories titled Kainovo naslijeđe [Cain's Legacy]. By reconstructing biblical stories (e.g., recounting the narrative about Dinah's brothers' revenge upon Shechem and his people), Dirnbah provides a profound frame of reference to understanding the basically tragic human condition throughout the long history of bloodthirsty warfare. In her novel Dnevnik jednog čudovišta [A Monster's Diary; Zagreb, 1997] she describes with wit and an acute critical voice the life of a teenager during the communist period. Her novel Kao mraz: Roman o nestajanju [Like a Frost: A Novel on Disappearance; Zagreb, 2000] portrays the history of a wealthy Jewish family who prospered in the leather industry. Their story encompasses a hundred years, including three wars, starting with their arrival from Hungary to Slavonia at the end of the nineteenth century and ending with the dramatic events that befell their offspring during the Yugoslav civil war in the 1990s.

Published toward the end of the twentieth century, Like a Frost portrays the difficulties the young generation faced because they grew up in a poisonous atmosphere perpetuated by the communist oppressive regime in the Yugoslav federation. Given the gap between them and their parents as Holocaust survivors, living in a society that killed the young generation's grandparents, her heroine suffers from disorientation and psychological disorders. The young generation's strong antagonism toward their parents and life as they knew it resulted in a compelling need to detach themselves from their parents' lives on the one hand, and the awareness of their specific "lot" as Jews who live in the unintelligible Balkans on the other hand. They feel that their complicated Balkanic environment is beyond what the outside world could understand. They experienced it as a state of mind that could not be shared even with their Jewish relatives living abroad. Consequently, despite the family stories about "a common grandmother," the young Jewish generation feels alienated from both their parents' generation and their relatives who live in other countries. 


\section{Ružica Galac-Popović (b. 1946)}

In her heartfelt novel Tircina slikovnica [Tirza's Album], ${ }^{16}$ Ružica GalacPopović-a writer and journalist who lived in Belgrade-describes the life of her father, a partisan leader who lost his leg in the war (and consequently suffered terrible phantom pains all his life), and a Jewish girl who lost her whole family and did not reveal to her daughter the fact of her Jewishness. The truth about her mother's Jewish origin, revealed to the daughter on her mother's deathbed, had a profound impact on the rest of the daughter's life.

As a journalist, Galac-Popović was involved in cultural activities of the Confederation of Jewish Communities, including interviewing Jewish writers and writing a great deal about Jewish issues. She published several books as well as poetry and prose. "In my home I was living with a mother who was a sole survivor, who carried the unbelievable burden of her life. She lived with past memories since oblivion was forbidden, while at the same time she was compelled to anticipate a different future. It means to have to carry all your life the heavy burden of the past. The Holocaust candle must burn forever, never to be extinguished," she told the public who came to celebrate the publication of her book on the Novi Sad Raid. ${ }^{17}$

\section{Nina Glišić-Aseo (1922-1993)}

Extensive evidential texts, poems, and stories can be found in the literary supplements of the Jewish Almanachs published annually by the Confederation of Jewish Communities in the former Yugoslavia, as well as in many documentary novels. ${ }^{18}$ Hana Menehem, ${ }^{19}$ by the Macedonian writer Nina Glišić-Aseo, belongs to what could be defined as "testimonial literature," written in a blunt realistic style which describes the particularities

${ }^{16}$ Ružica Galac-Popović, Tircina slikovnica (Beograd, 2001).

17 The "Novi Sad Raid," also known as the "Novi Sad massacre," the "Újvidék massacre," or simply "The Raid" (Racija), was a military operation carried out in January 1942 by the Honvédség, the armed forces of Hungary, during World War II. It resulted in the deaths of thousands of Jews and Serbs, all of them civilians, in the southern Bačka region of Hungarian-occupied Yugoslavia.

18 As Nema mjesta pod suncem (1959) by Danilo Nahmijas; Pod žutom trakom (1953) by Andreja Deak; and later on Razilaženja (1973) by Frida Filipović; Preskakanje senke (1989) by Ivan Ivanji; and others.

${ }_{19}$ Nina Glišić-Aseo, Hana Menehem (Beograd, 1984). 
of Holocaust events, their consequences as well as the victims' emotional state at the time and beyond.

Since under Tito's regime in the postwar multinational Yugoslav federation it was considered improper to openly discuss past atrocities committed by any Yugoslav individual —or a nation — toward another, there was at first a general tendency to repress that part of the past. The Jewish community was made up of a scarce number of survivors who found themselves in a peculiar position. Their major loss was considered part of the great general suffering and losses that the Germans inflicted on Yugoslavia. It was difficult to refer specifically to the disaster that happened to Jews and to their profound sense of betrayal (by local accomplices to the Germans) on the one hand. On the other hand, the part Jews played in the partisan movement's warfare against Germany was recognized and highly appreciated.

Hana Menehem provides clear testimony by describing how a well-to-do Jewish family of bankers was destroyed by close friends and acquaintances who collaborated with the Nazis. Glišić-Aseo succeeds in expressing both the unbearable feeling of betrayal and the impact of long-term trauma suffered by the survivors. While her protagonist does suffer from post-traumatic stress, he continues to believe that the world can and must be cured of hatred, and that repeated outbursts of blind hatred need not be permanent.

The growing long-term effect of the Holocaust became a central theme for writers occupied with questions concerning Jews and their post-Holocaust identity. The first works on those issues reflected the urge to provide pure testimony, such as Hana Menehem. Later, writers such as Danilo Kiš, Aleksandar Tišma, Filip David, David Albahari, Oskar Davičo, Erih Koš, Frida Filipović, Ana Šomlo, and Judita Šalgo provided additional testimonies which offered a broader as well as more sophisticated frame of reference to the issue. They all, however, avoided questions that bothered them as descendants of families and communities that were cruelly murdered on that same soil, frequently not only by the Germans but also by their local collaborators, especially in Croatia. However, in their writings, struggling with what happens to the literary hero as a Jew serves in many cases as a touchstone by which the society is evaluated or judged in a wide, universal context. This is characteristic of many literary works by Jewish writers. ${ }^{20}$

${ }^{20}$ To mention three of many examples: an allegory by Erih Koš, Vrapci van Pea (Beograd, 1962), the word "Pe" indicating an imaginary country, a phantasmagory by Oskar Davičo, Gospodar zaborava (Zagreb, 1980), or a novel by Judita Šalgo, Put u Birobidžan (Beograd, 1997). 


\section{Eva Grlić (1920-2008)}

In 1977 the journalist Eva Grlić, who had married a Communist Party member and fought with the Partisans against the Germans, published the first edition of an autobiography describing both the abuse and humiliation that Jews suffered under the Croatian Ustasha rule and her own sufferings as a political prisoner, who after the war was dispatched to the penal island of Goli Otok. ${ }^{21}$ She describes the killing of all her family members in Croatia and Bosnia, who during the war were sent to concentration camps (only she and her daughter survived), and how Jews, including the survivors, were robbed of their belongings.

A widow and mother of a daughter born in 1941, whose father, Eva's first husband Rudolf Domani, had been killed by the Ustasha, after the war she married Danko Grlić, a professor of philosophy. Because of his freethinking approach (regarding the Tito-Stalin split), Grlić was sent to Goli Otok, to be followed by his wife, who was imprisoned there for eight months. Their apartment was taken from them, her daughter sent to an orphanage, and upon her release Eva found herself homeless. Because she wrote a sentence in which she expressed disapproval, she was once again imprisoned in Goli Otok, this time for two years. In 1953 she was released, having lost sixteen teeth as well as her belief and trust in the system to which she had been devoted in her youth. Since she was forbidden to be a journalist, she worked as a secretary while editing and writing for the local factory paper, as well as publishing short stories. ${ }^{22}$ In her memoirs she mentions how she had been struck by the disapproval of her second husband's family not just because she was a widow and mother of a child, but "in addition to that, she was a Jew."

\section{Ženi Lebl (1927-2009)}

The Israeli writer and historian Ženi Lebl came to Israel following two and half years of imprisonment in Goli Otok (she was sentenced for having told an innocent joke). In addition to a monograph about the Jews of Macedonia ${ }^{23}$ and a catalogue of Jewish books published in Belgrade between 1837 and

${ }^{21}$ Eva Grlić, Sjećanja: Autobiografska fikcija o životu prije i poslije rata (Zagreb, 1998).

22 Eva Grlić, Putnik za Krakow i druge priče (Zagreb, 2002).

23 Ženi Lebl, Ge'ut va-shever / Plima i slom (Jerusalem, 1986/1990). It is a history of the Jews of Vardar, Macedonia, published first in Hebrew and later in Serbo-Croatian. 
$1905,{ }^{24}$ Lebl published a study on the Jerusalem Mufti, first in Serbian, ${ }^{25}$ then in Hebrew, ${ }^{26}$ and later translated into English. ${ }^{27}$ In 2001 she published a comprehensive two-volume history of the Jews of Serbia and of Belgrade, both also published in Serbian, Hebrew, and English. ${ }^{28}$ She also published two autobiographical books in both Hebrew and Serbian, as well as a brief history and biographical dictionary of Jews from the former Yugoslavia living in Israel, in a Hebrew and Serbian bilingual edition. ${ }^{29}$

In her novel Dnevnik jedne Judite [Diary of a Judith] ${ }^{30}$ Lebl describes the harsh times of the German occupation by writing an imaginary diary on behalf of her mother, sharing her observations, thoughts, and feelings in occupied Belgrade with her husband, who had been taken as prisoner to a German camp. In the Serbo-Croatian version of her autobiography Lebl wrote:

We, Yugoslav Jews, truly believed in equality of rights and obligations in our homeland. But can we now regard it as our homeland? We were not in the least prepared for the blows, and consequently felt betrayed. We lost our belief in humanity. More than anything, my mother was hurt by the thundering silence of our non-Jewish neighbors and friends. The minimal protests-if at all-were lost in the silence of the majority that did not shun the new laws and thus eventually agreed with them. Suddenly the laws became more forceful, since they struck our home and environment. For me it was the first major disappointment, leaving a painful scar. ${ }^{31}$

In addition to the above works, Lebl published dozens of short studies and articles in both Hebrew and Serbian, winning over the years 26 first prizes in anonymous annual contests organized by the Confederation of Jewish Communities in Belgrade to encourage historical, literary, and scholarly works about the lives of Jews in Yugoslavia. She also translated a great deal of modern Hebrew poetry into Serbo-Croatian.

In the first of her two autobiographical books she depicted imprisonment at Goli Otok. ${ }^{32}$ In the second book, published in 1997, she described

24 Ženi Lebl, Jevrejske knjige štampane u Beogradu 1837-1905 (Gornji Milanovac, 1990).

${ }_{25}$ Ženi Lebl, Jerusalimski muftija (Beograd, 1993).

${ }^{26}$ Ženi Lebl, Haj Amin \& Berlin (Tel Aviv, 1996).

27 Ženi Lebl, The Mufti of Jerusalem Haj-Amin el-Husseini and National-Socialism (Belgrade, 2007).

${ }_{28}$ Ženi Lebl, Do konačnog rešenja (Beograd, 2001, 2002).

${ }_{29}$ Ženi Lebl, Juče, Danas: Doprinos Jevreja sa teritorije bivše Jugoslavije Izraelu (Tel Aviv, 1999).

30 Ženi Lebl, Dnevnik jedne Judite: Beograd 1941 (Beograd, 1990).

31 Ženi Lebl, Odjednom drukčija, odjednom druga (Beograd, 2008), 18. Unless otherwise noted, the quotations are translated by the author of the article.

32 Ženi Lebl, Ljubičica bela (Beograd, 1990; 1993; 2009). It is an autobiography about Yugoslav Women's Gulag, published in Serbo-Croatian and in Hebrew. 
the first chapter of her life, how as a young girl she fled from occupied Belgrade and finally arrived at the Gestapo prison in Berlin, at the last moment to be saved by the Russians from a death sentence imposed by the Germans (ordered by Heinrich Himmler, to celebrate Hitler's birthday). ${ }^{33}$ Upon returning to Belgrade she learned that her mother and grandmother had been dispatched to the local Sajmište concentration camp and were gassed to death in the German vehicle designed for that purpose.

On her return to Belgrade from Berlin, Lebl began a new period full of promising opportunities, but was soon again a victim of a cruel, unexpected fate. In her own words (translated from Hebrew):

Here ends another chapter of my 18-year old life and a new one begins. In two years I completed secondary school and passed the matriculation examination. I enlisted as a student at the High School of Law and Diplomacy and started working as a journalist for Politika. I succeeded in overcoming the past. Once again the sun was shining. I thought that I would never again be altered or different, that the question to be or not to be would never arise again. I had no idea that in a short while I was to become a victim of malicious slander. I did not know that other people wrote the screenplay and were to direct my life, whereas I became the star playing the main role. I had no idea that soon, very soon, I would know and feel the dark side of the sun. About that-in my book Ha-sigalit ha-levana [The White Violet.$^{34}$

In Lebl's autobiographies as well as in her novel Diary of a Judith the personal testimony as a prosodic strategy - the attempt to provide personal evidence, a factual testimony - is based on meticulous historical research. Her obvious talent as a storyteller seems to be her ability to describe a chapter in history as a fascinating and moving life story, endowed with shrewd personal insights.

\section{Julija Najman-Klopfer (1905-1989)}

Among the women with careers in media and communications was the journalist and writer Julija Najman, who interviewed leading personalities of her time (Jean-Paul Sartre, Eugène Ionesco, Jean Cassou, Louis Aragon, Arthur Miller, and Nathalie Sarraute). As a writer she had great interest in women's issues, and wrote "short journalistic anecdotes with a keen

\footnotetext{
33 Ženi Lebl, Pitom shona, Pitom aheret (Jerusalem, 1997), 190.

${ }^{34}$ Ibid., 241.
} 
realistic ability to note human weaknesses and unusual circumstances." 35 Her literary opus includes short stories and novels as well as several dramas, always faithful in portraying "real life."

However, as we read her stories describing the trials and tribulations of a Jewish woman who with two small children fled to Italy and had to live there under a false identity, overwhelmed by the fear of being identified as a Jewish refugee, it appears that the technique of "reconstructing" life situations yields in her case more than just a mere realistic description of everyday difficulties. The life story of her heroine in these stories is in a way an image of a Jewish woman's position as a persecuted creature with a specific state of mind. This is obvious even in the titles of her novels Šapat [A Whisper] or Nameštanje lica [The Adjustment of Faces]. ${ }^{36}$ Such texts reflect the psychology of hiding when "adjustment of faces" becomes the only strategy to provide a chance of survival.

Najman describes various types of women whom she had to pretend to be occasionally, asking herself endlessly which one of them could have saved her at a given moment. Thus her writing deals basically with appearance as opposed to essence, false against genuine, pretence against truth, when both choices seem questionable for providing help, rescue, or safety. She shows how the self-consciousness of a refugee fleeing from death becomes an issue, as pretence produces manipulation along with paralyzing fear, while self-denial becomes the inevitable price that a persecuted creature must pay for the sake of survival.

\section{Magda Bošan Simin (1922-2004)}

Magda Bošan Simin was an editor in chief of Radio Novi Sad and a former member of the Federal Parliament in Vojvodina. As a member of the Communist Party she was imprisoned by the Germans first in Hungary and then in Bergen-Belsen. Her documentary writings describe the suffering of those times. After the war she completed her studies, was active in many organizations, and wrote short stories, plays, novels, and memoirs. ${ }^{37}$

${ }^{35}$ Predrag Palavestra, Jewish Writers in Serbian Literature, trans. George Nikolić (Belgrade, 2003), 113.

36 Julija Najman, $\check{S}$ apat (Beograd, 1968). It is a short-story collection on Jewish themes. Nameštanje lica (Beograd, 1979) is a novel based on wartime experiences.

${ }^{37}$ Magda Simin, Izdanci na vetru (Novi Sad, 1958); Pomračenja (Novi Sad, 1972); San mladosti (Novi Sad, 1983); the novels Kamen na ramenu (Novi Sad, 1988) and the travellogue Beleške iz Izraela (Novi Sad, 1990). 
Simin details the hardships of political prisoners in German camps. The Jewish aspect is less present in her writings; she does not reflect on issues of identity and destiny, and the Jewish angle is present rather as a mere "casual" fact. However, in describing the long convoys of Jewish Austrian refugees (before their deportation), she remembers that upon seeing them her father attached a mezuzah to the doorpost of their family home.

In most of her writings communism is presented as the solution to the Jewish problem. Nevertheless, she mentions that each time she "forgets that she is Jewish there is somebody to remind her of it," 38 and in a way she is unaware of the implications of such a statement.

In Novi Sad, women who had been imprisoned during World War II for their active participation in warfare against the German occupation kept annual gatherings. One such meeting was dedicated to Magda Simin's book Bačvanske političke osuđenice u ratu 1941-1945 [Women from Bačka: Political Prisoners in the War 1941-1945]. ${ }^{39}$ What Galac-Popovic (whose mother was one of those women) had to say on that occasion seems to sum up the literary opus of Magda Simin as well as Simin's own strategy of retaining the memory of that specific passage of the "feminine voyage":

If you donate a life to your son, it is too little; if another one goes to your husband-it is too little; if you give the third one to your work-it is too little; if you fight for ideals - it is too little ... while all those women, still "too little," have been carrying all that on their hands throughout their prolonged lifeline-now joined by grandchildren and great-grandchildren, whose youth was marked by the bloody sentence of history.

As to their number and the various prisons in which they were held, Magda Simin, authoring Women from Bačka: Political Prisoners in the War 1941-1945, the publication which we are celebrating today, reminds us not only by providing the sheer document, but through the lyric story as well, as it is usually the case with a woman (men would say it is too pathetic).

Galac-Popović then says that although Magda Simin's family resented her re-experiencing the time of the war, the drive to write it all down was stronger, since it was important for her not only as a document, but also as a piece of "the feminine gentleness," which was not lost in those times of

${ }^{38}$ Magda Simin, Dok višnje procvetaju (Zagreb, 1980), 185.

${ }^{39}$ Further bibliographical information is unavailable. Galac-Popović delivered her speech on the occasion of celebrating Simin's book on women war prisoners. See "I sedam života je malo," Skup vojvođanskih logorašica nakon 58 godina, vojvodina.com (29 Oct. 2003), http://www.vojvodina.com/zanimljivosti/arhiva3/031029.html [retrieved: 24 Jan. 2018]. 
cruelty. It tells how "four of our fellow women gave birth in those prisons, and that in spite of feeding on the bromine-soup and losing our period, most of us have lived to experience the bliss of motherhood." Another aspect is the story of those women's lives, which does not end with their getting out of evil prisons and camps; it also reveals their postwar lives, as many became top professionals in fields such as medicine, pedagogy, journalism, and art. ${ }^{40}$

\section{Mirjam Štajner-Aviezer (b. 1935)}

Mirjam Štajner-Aviezer, born in Slovenia, came to Israel as a young woman after working with young Jews in Belgrade. Although she published several short stories and monographs about the Righteous Among the Nations, she is best known for her unique novel Vojak z zlatimi gumbi [The Soldier with the Golden Buttons], published in Serbo-Croatian (1964) and translated into Hebrew and other languages. ${ }^{41}$

The novel tells the story of a group of young Jewish children on their way to a German camp and their life in it. It reveals physical and mental horrors as contemplated by a young innocent girl, who feels rather than understands what is happening around her. The girl is endowed with a rich imagination and notions about the grown-up world which she acquired in her parental home, where culture and well-being predominated. The story marks her experiences as a young sensitive child torn from her parents, bewildered at the atrocities surrounding her.

The story of Štajner-Aviezer's small heroine is rich in visual as well as emotional content, brilliant in its powerful description of the clash that the young child experiences between innocence, the sense of beauty, the yearning for love, the longing for a "normal" life, while confronted with the cruelty of the Nazi soldier who hits and abuses the children and even burns one of them in front of the young inmates' eyes. Yet at the same time the girl responds to the German soldier's beautiful external appearance. His aesthetic appearance attracts the little girl's attention, misleading her to interpret beauty as promising some kind of redemption, as the attractive glittering buttons on the German soldier's uniform apparently represent

${ }^{40}$ Ibid.

${ }^{41}$ Mirjam Štajner-Aviezer, Ha-hayal ba'al kaftorei ha-zahav, trans. Yohanan Omri (Tel Aviv, 1977). For the English edition see Miriam Steiner-Aviezer, The Soldier with the Golden Buttons, trans. Miriam Arad (Jerusalem, 1987). 
something that by the power of sheer beauty is in her young mind associated with an orderly world permeated with kindness. The strong impact of the sight of the German soldier's uniform on the child's senses relates to a sense of order, politeness, and security, associated with the aesthetic aspect of her surroundings. The soldier's beautiful uniform makes her associate his appearance with the orderly cultural world that she had known, and she expects the soldier in the handsome uniform to put an end to the unintelligible suffering that she actually experiences. Further on, by sticking to the inner mute words of a very young child, ŠtajnerAviezer describes the unbearable pain of the growing misunderstanding between a young child and her mother in the hard circumstances of the German camp, due to the little girl's inability to understand what has happened to her and to her mother. The child seems to mutely blame the mother for "allowing it" to happen. On the other hand, in a moving way the young girl's innocent view manifests a child's moral victory amidst the surrounding arbitrary evil and unintelligible cruelty.

\section{Conclusion}

Literature from the former Yugoslavia frequently raises questions about Jewish existence while searching for new definitions of Jewish identity to fit the modern era with its secular atmosphere and unavoidable assimilation. Consequently, it both expresses the fear of disappearance of the community and recognizes the importance and validity of Jewish age-old wisdom, threatened as a spiritual resource. In this context the complex relation of one's Jewish origin almost never incorporates the religious patterns of belonging to Judaism; instead, it focuses in many ways on trends of thought, modes of behavior and moral values that could be re-interpreted and applied to different life circumstances.

Whoever survived the Holocaust, whether as a child or as a youth, expressed in various ways the break in continuity of their Jewish life and consciousness. The dominant feeling was that life was composed of fragments of authentic experiences, of particles of times and events, marked by a real sense of loss and overbearing chaos. Consequently, it was necessary to establish a new order of priorities, to attempt to reconstruct the lost continuity in terms of individual memory, family life, and a communal frame of reference. In these cases, each specific cultural heritage provided writers with a referential context and a sense of belonging to a cultural 
legacy. Jewish writers preserved (even in altered circumstances) some of their original common codes from the Old Testament and the Talmud. The meaning of such codes might be open to different interpretations, but they definitely sprang from ancient common sources. This link is present in the writings of Ana Šomlo, Zora Dirnbah, Judita Šalgo, and Jasminka Domaš, and in many cases is implied in the other authors as well.

On 23 October 1992 at an evening dedicated to "The Jewish Identity of Our Times,” Judita Šalgo spoke about her childhood experience of being separated from her mother who was sent to a Nazi camp. Judita was brought up by a woman whom she had to call Mommy, and whom she loved although she knew that her "real one" was far away. Šlgo explained that it was very difficult for her to relate to her mother with love once "the real one" returned from the camp tortured, filthy, and miserable. Šalgo concluded that we are living in times when everything-including one's own mother-seems replaceable. This left her with a feeling of deep skepticism and insecurity. In her speech delivered that evening Šalgo commented on her Jewish identity:

The Jewish identity is expressed, in life and in literature, by a certain repertoire of themes, symbols, general places, and prejudices: Zion, the Temple, holy scriptures, exclusion, migrations, the Diaspora, the Holocaust, deracination, separation, Jewish solidarity, Jewish self-hatred and racial shame, Jewish arrogance, Jewish skepticism and negativism, cosmopolitanism, revolutionary subversion, humor, humanist altruism, thriftiness, greed, petty bourgeois boastfulness, class tolerance, business, artistic and scholarly talents, neuroses. ... My national identity manifests itself through an absence of unequivocal categories: I both am and am not that which is expected of me (and which I expect of myself), I both am and am not at home, both do and do not want to be what I am and where I am, and so on. If once in the future - to introduce a poetic projection-Jews would stop migrating, and then, in time, their memories and dreams would stop wandering, that fabulous "identity" would calm down as well, and the Jew would unite with himself (that would happen in literature). If my literary protagonists are wandering, that may be for just two reasons: either because they are Jews or because I am a poor writer. ${ }^{42}$

Jewish writers (men and women alike) recognized themselves as descendants of an age-old tradition encompassing turmoil and mixed marriages.

${ }^{42}$ Translated into English partly by George Nikolić and partly by myself from: Judita Šalgo, "Moj jevrejski identitet," in ead., Jednokratni eseji (Beograd, 2000), 129-135. 
Despite that, they all found a way to maintain their faith, if only as carriers of some remnants of the broken Tables of Testimony. The literature written by these very few Jewish Holocaust survivors is permeated with feelings of disappointment and disillusion as well as a deep sense of betrayal. Yet each writer demonstrates a unique perspective on what it meant to be a Jew during the Holocaust and what it means to be a Holocaust survivor in the aftermath.

Women writers are evidently aware of the feminine "lot." Whether writing about their own or their female protagonists' experiences, Jewish women writers describe in so many ways a world dominated by strife, striving to formulate their view of Jewish destiny in past times while looking forward toward a horizon of hope for a better future.

\section{Appendix: List of Jewish Women Writers in Former Yugoslavia}

Alfandari Pardo, Reli (1929-)

Altaras, Gina (1896-?)

Bogičević-Švarcenberg, Nina (1944-)

Bojetu-Boeta, Berta (1946-1997)

Bojović, Zlata (1939-)

Bošković, Magda (1914-1942)

Braude-Kovačević, Mina (1920-)

Cvejin, Tatjana (1948-2011)

Demajo, Vesna (?)

Dirnbah, Zora (1929-)

Domaš, Jasminka (1948-)

Filipović, Frida (1913-2003)

Galac-Popović, Ružica (1946-)

Glišić-Aseo, Nina (1922-1993)

Grgelj, Boriska (1889-1944)

Grlić, Eva (1920-2008)

Ivanji, Ildi (1933-)

Jun-Broda, Ina (1899-1983)

Kabiljo-Šutić, Simha (1938-2008)
Kalderon-Petković, Slobodanka (1942-)

Kolonomos, Žamila (1922-2012)

Kuić, Gordana (1942-)

Lebl, Ženi (1927-2009)

Lebl-Albala, Paulina (1891-1967)

Lerinc, Ruza (1915-1941)

Nahman-Premeru, Sonja (1904-1986)

Najman-Klopfer, Julija (1905-1989)

Ovadija, Rikica (1913-?)

Papo Levi, Laura, Bohoreta (1891-1941)

Rajner-Vajner, Mirjam (1959-)

Šalgo, Judita (1942-1996)

Simin Bošan, Magda (1922-2004)

Šomlo-Ninić, Ana (1935-)

Srdanović-Barać, Olga (?)

Štajner-Aviezer, Mirjam (1935)

Tutunović, Drita (1944-)

Zrnić, Maja (1961-)

Dina Katan Ben-Zion dikaben37@gmail.com 